\title{
Australian Female Board Representation
}

\author{
Xiaoyang Song \\ University of Newcastle, Australia
}

\begin{abstract}
This article provides a descriptive analysis of the increase in female directors on Australian company boards from 2001 to 2010. After outlining the female board representation of the largest 500 companies in Australia based on their ASX market capitalisation from 2001 to 2010, an overall snapshot of the female participation on boards is based on a general, industry, corporate and individual level. With an increasing representation since 2001 to 2010, female directors consistently have more seats in the boardrooms of Insurance and Banking companies; while in Energy, Materials and Utilities sectors, female directors have been under-represented. In addition, female directors are most likely to serve on Audit Committee and are more likely to chair Audit Committee and Remuneration Committee. The findings of this article examine the effectiveness of existing gender diversity initiatives and shed a light on future corporate governance proposals advocating greater gender diversity on company boards.
\end{abstract}

\section{Introduction}

In recent years there has been growing world-wide interest in the importance of female participation in business practices, among both scholars and the business community (Jurkus, Park, \& Woodard, 2008; Nielsen \& Huse, 2010; Nielsen \& Morten, 2010; O'Reilly III \& Main, 2012; Wellalage, 2011). This, to a great extent, is due to the significant role people legitimately expect females to play in global business activities. However, the evidence suggests that females still constitute a relatively small percentage of directors on corporate boards. For example, in the United States, based on the 500 companies in the survey of Corporate Women Directors International (CWDI) in 2012, women held 16.1 percent of the board seats (CWDI, 2012). In other countries, there is a similarly small proportion of female representation on corporate boards. For example, based on the data of the European Professional Women's Network (EPWN), in Germany only 11.2 percent of company directors were women in 2004 and this number rose slightly to 14.1 percent in 2014 (Catalyst, 2014). In Canada the proportion of female directors on company boards was 10.3 percent, while in Japan it was only 1.1 percent (Catalyst, 2014). Similar surveys have been performed by the Equal Opportunity for Women

Copyright (C) 2015 Victoria University. This document has been published as part of the Journal of Law and Governance in both online and print formats. Educational and non-profit institutions are granted a non-exclusive licence to utilise this document in whole or in part for personal or classroom use without fee, provided that correct attribution and citation are made and this copyright statement is reproduced. Any other usage is prohibited without the express permission of the publisher. in the Workplace Agency (EOWA) for female director representation on Australian company boards. There is evidence indicating a modest progression in Australian female board representation over the last decade. Australia generally reports substantial levels of participation of women in the workforce, however only a tiny percentage of this substantial group occupy leadership roles or top positions. 
According to the EOWA census ${ }^{1}$, only 8.2 percent of board seats in ASX top 200 companies were held by women in 2004 (EOWA, 2010). This figure only rose slightly to 8.4 percent in 2010, although in the following years Australia increased this representation to a level above that of Canada and New Zealand. More recently there were some promising developments regarding women in senior business positions. For example, in 2012, 61.5 percent of the ASX $200^{2}$ companies had at least one female director on their boards, and women made up 12.3 percent of the ASX 200 directorships and 9.2 percent of the ASX 500 ${ }^{3}$ directorships (EOWA, 2012). More recent data in March 2014 shows that Australia currently claims the highest rates of female board participation in the Asian-Pacific region and is rising on an international comparative basis (see Figure 1).

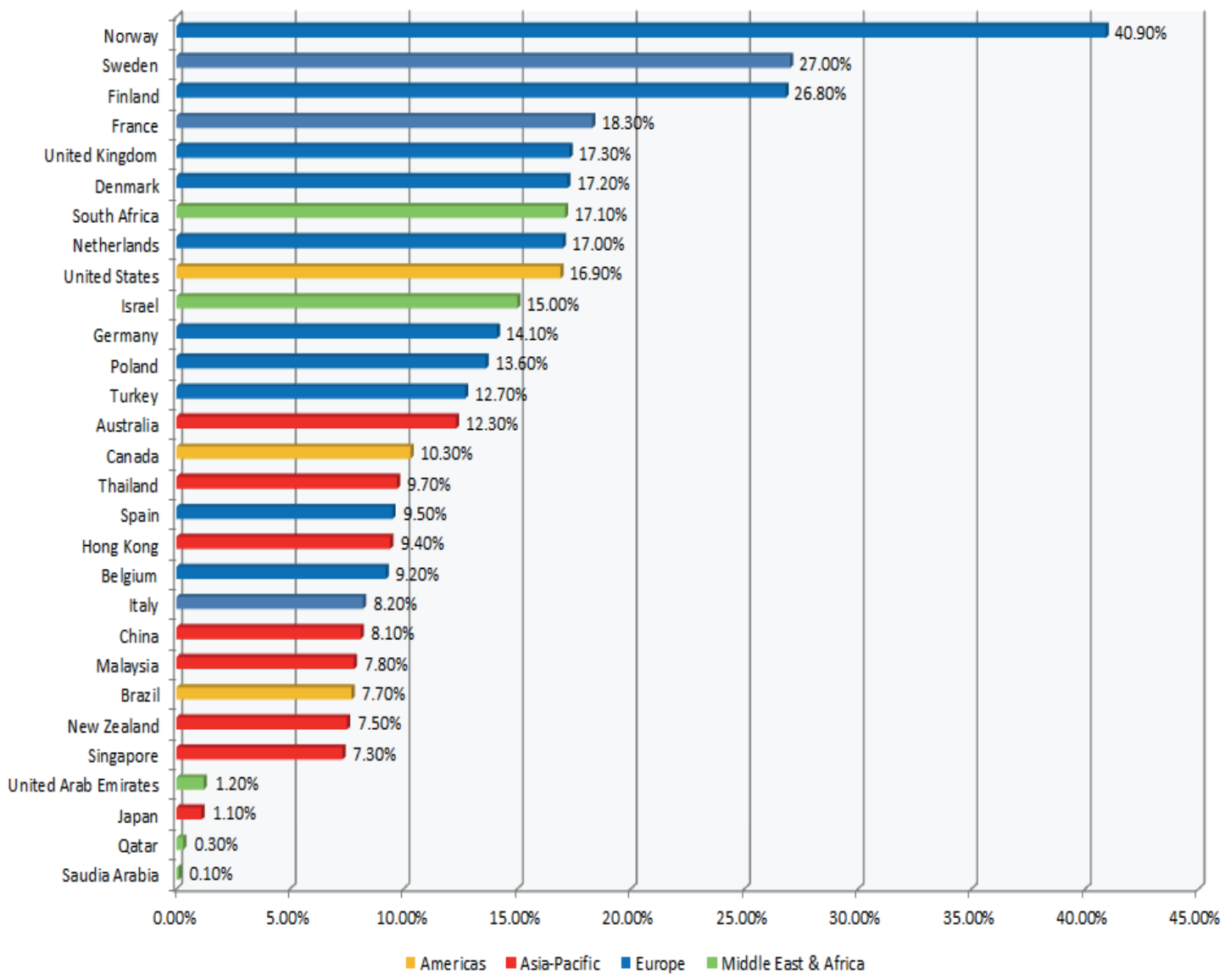

Figure 1 Worldwide female director representation

Source Catalyst (2014)

Based on the data of Australian Census of Women in Leadership, a trend of increasing participation of women in both boardrooms and executive teams has occurred from 2002 to 2012. As mentioned above, women held only 8.2 percent of ASX 200 directorships in 2002. While being a long way short of achieving gender parity, there was a significant improvement in directorships being held by women by 2012 (see Figure 2). By this date, the percentage of ASX 200 companies with at least one female

\footnotetext{
${ }^{1}$ Australian Census of Women in Leadership.

2 The ASX 200 refers to ASX 200 index companies as at 16 March 2012. The ASX 200 index measures the performance of the 200 largest index-eligible stocks listed on the ASX by float-adjusted market capitalisation.

${ }^{3}$ The ASX 500 refers to ASX 500 index companies as at 16 March 2012. The ASX 500 index refers to the All Ordinaries Index comprising the 500 largest securities listed on the ASX and the constituents are not screened for liquidity. The index is not float-adjusted.
} 
director had also improved significantly to 61.5 percent. Finally, in 2012, 43.8 percent of the ASX.

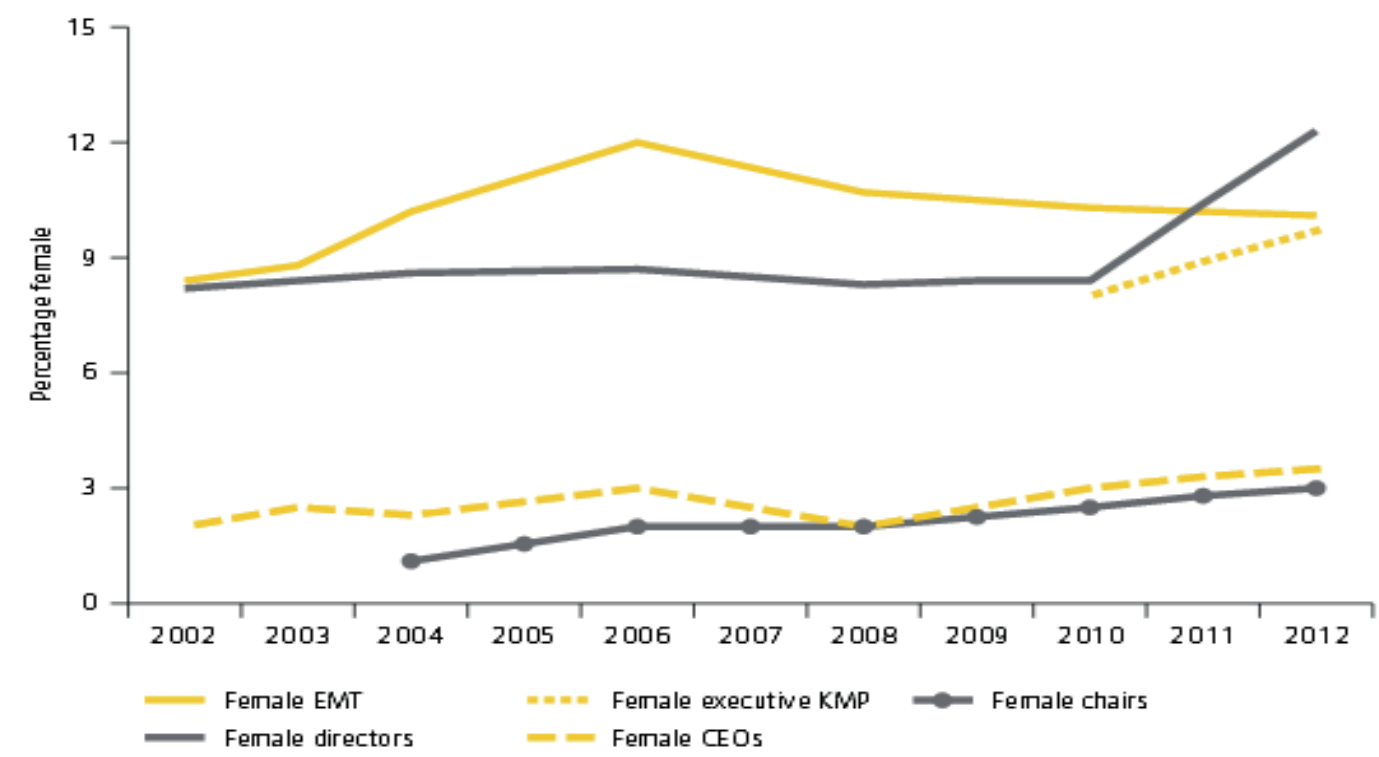

Figure 2 Female representations in leadership in ASX 200 companies (2002-2012)

Source:EOWA (2012).

\section{General descriptions of female directors from 2001 to 2010}

This article outlines the female board representation of the largest 500 companies $^{4}$ in Australia based on their ASX market capitalisation from 2001 to 2010. An overall snapshot of the female participation on boards is based on a general, industry, corporate and individual level. The sample size in different years which are examined are represented in the table below (see Table 1). The research period is from 2001 to 2010 .

Table 1 Sample size in different years

\begin{tabular}{|l|l|l|l|l|l|l|l|l|l|l|l|}
\hline Year & $\mathbf{2 0 1 0}$ & $\mathbf{2 0 0 9}$ & $\mathbf{2 0 0 8}$ & $\mathbf{2 0 0 7}$ & $\mathbf{2 0 0 6}$ & $\mathbf{2 0 0 5}$ & $\mathbf{2 0 0 4}$ & $\mathbf{2 0 0 3}$ & $\mathbf{2 0 0 2}$ & $\mathbf{2 0 0 1}$ & Total \\
\hline Firm & 500 & 483 & 478 & 454 & 425 & 396 & 358 & 311 & 299 & 283 & 3,987 \\
\hline
\end{tabular}

\footnotetext{
4 The list of the largest 500 companies ranked by their ASX market capitalisation was collected based on the market capitalisation on the end of 2010.
} 


\section{Changes of female director representation over time}

Based on the sample data, the female directorships on company boards are represented in Figure 3. Both the percentage of female directors and percentage of companies with at least one female director have increased between 2001 and 2010. In terms of representation on company boards, the percentage of female directors in the sample companies rose slightly from 5.05 percent in 2001 to 6.71 percent in 2010. However, a more significant increase saw a 24.53 percent increase in sample companies with at least one female director from 26.50 percent in 2001 to 33.00 percent in 2010. In particular, it should be noted that the figures have shown a small reduction from 2007 to 2009 which possibly could be attributed to the global financial crisis.

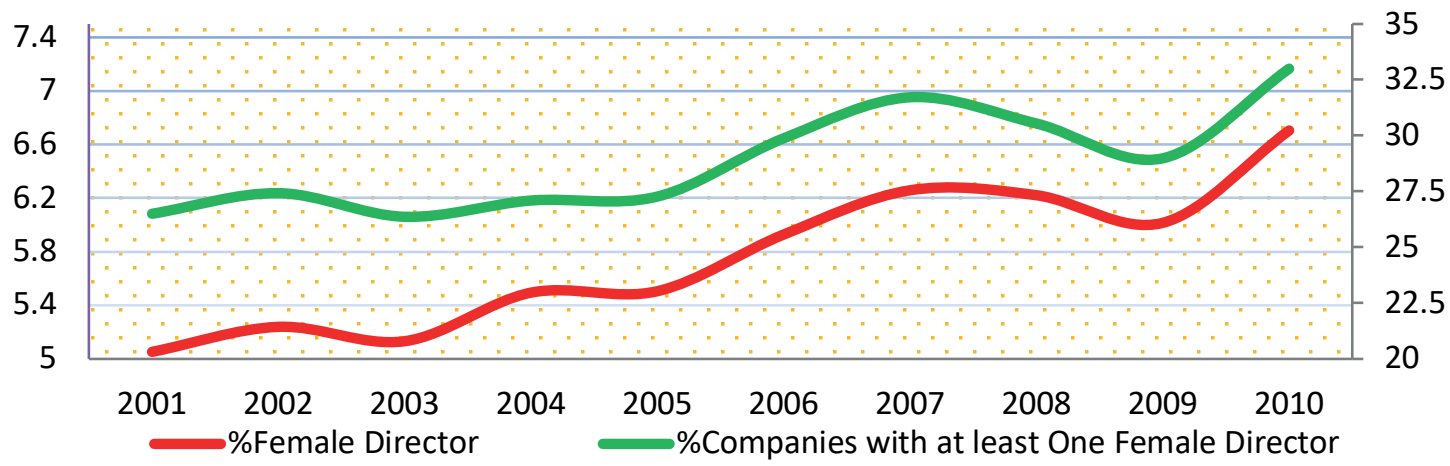

Figure 3 General description of female representations on boards (2001-2010)

\section{Female director representation and company size}

Hillman, Shropshire, and Cannella (2007) found that larger companies are more likely to have a greater number of female directors on their board. This finding is supported by the results of EOWA (2012) showing that more female directors are found in larger companies based on their ASX market capitalisation (see Table 2). In this study, as utilised in other literature (Adjaoud \& Ben-Amar, 2010; Carter, Simkins, \& Simpson, 2003), total assets of the sample companies are used to measure company size. A clear relationship between the percentage of female directors and company size is indicated in Figure 4. Following the classification criteria of EOWA (2012), the sample companies are ranked and categorised into five groups based on their total assets: Rank 1-20, Rank 21-50, Rank 51-100, Rank 101-200, and Rank 201-500. As the sample size is smaller in the years 2001 to 2009, a proportion is used in these sample companies, Rank top 4\%, Rank $>4 \%-10 \%$, Rank $>10 \%-20 \%$, Rank $>20 \%-40 \%$, and others. The range of total assets for each group is shown in Table 3 .

Table 2 Female directors and company size in 2012

\begin{tabular}{|l|r|r|r|r|r|}
\hline Company size & ASX & ASX & ASX & ASX 101- & ASX 201- \\
& Top 20 & $21-50$ & $51-100$ & 200 & 500 \\
\hline Percentage of female directors & $18.8 \%$ & $15.7 \%$ & $11.8 \%$ & $9.1 \%$ & $6.1 \%$ \\
\hline
\end{tabular}

Source: (EOWA, 2012). 
Table 3 Company size and classification in the sample companies

\begin{tabular}{|c|c|c|c|c|c|}
\hline \multicolumn{6}{|l|}{2001 (283 Firms) } \\
\hline Company size & Rank 1-11 & Rank 12-28 & Rank 29-57 & Rank 58-113 & $\begin{array}{c}\text { Rank 114- } \\
283\end{array}$ \\
\hline $\begin{array}{l}\text { Total assets (\$ } \\
\text { million) }\end{array}$ & $\begin{array}{l}27,848- \\
374,720\end{array}$ & $4,825-19,585$ & $1,564-4,222$ & $251-1,546$ & $0.57-244$ \\
\hline \multicolumn{6}{|l|}{2002 (299 Firms) } \\
\hline Company size & Rank 1-12 & Rank 13-30 & Rank 31-60 & Rank 61-120 & $\begin{array}{c}\text { Rank 121- } \\
299\end{array}$ \\
\hline $\begin{array}{l}\text { Total assets (\$ } \\
\text { million) }\end{array}$ & $\begin{array}{l}30,234- \\
377,387\end{array}$ & $4,030-20,537$ & $1,695-3,907$ & $264-1,669$ & $0.10-252$ \\
\hline \multicolumn{6}{|l|}{2003 (311 Firms) } \\
\hline Company size & Rank 1-12 & Rank 13-31 & Rank 32-62 & Rank 63-124 & $\begin{array}{c}\text { Rank 125- } \\
311\end{array}$ \\
\hline $\begin{array}{l}\text { Total assets (\$ } \\
\text { million) }\end{array}$ & $\begin{array}{l}31,610- \\
397,471\end{array}$ & $4,355-20,478$ & $1,741-4,038$ & $268-1,725$ & $0.03-262$ \\
\hline \multicolumn{6}{|l|}{2004 (358 Firms) } \\
\hline Company size & Rank 1-14 & Rank 15-36 & Rank 37-72 & Rank 73-143 & $\begin{array}{c}\text { Rank 144- } \\
358\end{array}$ \\
\hline $\begin{array}{c}\text { Total assets (\$ } \\
\text { million) }\end{array}$ & $\begin{array}{l}25,102- \\
411,309\end{array}$ & $4,376-17,574$ & $1,499-4,346$ & $265-1,489$ & $0.21-255$ \\
\hline \multicolumn{6}{|c|}{2005 (394 Firms, 2 firms no size data is available) } \\
\hline Company size & Rank 1-16 & Rank 17-40 & Rank 41-79 & Rank 80-158 & $\begin{array}{l}\text { Rank 159- } \\
394\end{array}$ \\
\hline $\begin{array}{l}\text { Total assets (\$ } \\
\text { million) }\end{array}$ & $\begin{array}{l}17,147- \\
419,588\end{array}$ & $4,697-13,262$ & $1,865-4,636$ & $286-1,737$ & $0.18-285$ \\
\hline \multicolumn{6}{|c|}{2006 (422 Firms, 3 firms no size data is available) } \\
\hline Company size & Rank 1-17 & Rank 18-42 & Rank 43-84 & Rank 85-169 & $\begin{array}{c}\text { Rank 170- } \\
422\end{array}$ \\
\hline $\begin{array}{c}\text { Total assets (\$ } \\
\text { million) }\end{array}$ & $\begin{array}{l}16,972- \\
484,785 \\
\end{array}$ & $5,587-16,927$ & $2,019-5,397$ & $352-1,961$ & $0.12-343$ \\
\hline \multicolumn{6}{|c|}{2007 (452 Firms, 2 firms no size data is available) } \\
\hline Company size & Rank 1-18 & Rank 19-45 & Rank 46-90 & Rank 91-181 & $\begin{array}{c}\text { Rank 182- } \\
452\end{array}$ \\
\hline $\begin{array}{l}\text { Total assets (\$ } \\
\text { million) }\end{array}$ & $\begin{array}{l}20,037- \\
564,634\end{array}$ & $5,912-19,606$ & $2,306-5,851$ & $460-2,188$ & $0.11-454$ \\
\hline \multicolumn{6}{|l|}{2008 (478 Firms) } \\
\hline Company size & Rank 1-19 & Rank 20-48 & Rank 49-96 & Rank 97-191 & $\begin{array}{c}\text { Rank 192- } \\
478\end{array}$ \\
\hline $\begin{array}{c}\text { Total assets (\$ } \\
\text { million) }\end{array}$ & $\begin{array}{l}19,700- \\
656,799\end{array}$ & $6,464-19,380$ & $2,325-6,122$ & $538-2,325$ & $0.20-536$ \\
\hline
\end{tabular}


Table 4 Company size and classification in the sample companies (Continued)

\begin{tabular}{|c|c|c|c|c|c|}
\hline $\mathbf{2 0 0 9}$ (483 Firms) \\
\hline Company size & Rank 1-19 & Rank 20-48 & Rank 49-97 & Rank 98-193 & $\begin{array}{c}\text { Rank 194- } \\
\mathbf{4 8 3}\end{array}$ \\
\hline $\begin{array}{c}\text { Total assets (\$ } \\
\text { million) }\end{array}$ & $\begin{array}{c}22,102- \\
654,120\end{array}$ & $6,339-20,049$ & $2,261-6,284$ & $524-2,225$ & $0.01-515$ \\
\hline $\mathbf{2 0 1 0}$ (499 Firms, 1 firm no size data is available) \\
\hline Company size & Rank 1-20 & Rank 21-50 & Rank 51-100 & $\begin{array}{c}\text { Rank 101- } \\
\mathbf{2 0 0}\end{array}$ & $\begin{array}{c}\text { Rank 201- } \\
\mathbf{4 9 9}\end{array}$ \\
\hline $\begin{array}{c}\text { Total assets (\$ } \\
\text { million) }\end{array}$ & $\begin{array}{c}19,910- \\
685,952\end{array}$ & $5,761-19,872$ & $2,210-5,711$ & $560-2,163$ & $4-559$ \\
\hline
\end{tabular}

As indicated by Figure 4, in general, larger companies are more likely to have female directors than smaller companies, and they are also more likely to have a higher percentage of female directors. Although in 2001 the proportion of female directors was only 9.57 percent in the TOP $4 \%$ sample companies, there was a significant increase of up to 18.50 percent by 2010. According to EOWA census data, female director representation had generally increased in companies of all sizes by the end of 2012. Beyond this general trend however, the percentage and number of female directors do show some difference according to the different levels of company size (see Figure 4).

As indicated in Figure 4 and Figure 5, there was a general increase in the percentage of female directors until 2010 for all sample companies except for the Rank 4\%-10\% sample companies.

The Top 4\% sample companies continually have the highest figures in terms of gender diversity with increases occurring consistently. This trend is less apparent in the $10 \%-20 \%, 20 \%-40 \%$ and other sample companies.

Rank 4\%-10\% sample companies showed very different patterns than those discussed above. From a starting point of 14.10 percent as the percentage of female directors in 2001, this number fell to 11.20 percent in 2010. In 2009, there was a transitory increase for the percentage of female directors while the numbers of female directors were the same as 2008. Another specific trend emerges in the Rank $10 \%-20 \%$ sample companies, in which the percentage of female director peaked in 2003 but followed a continuous decline with a slight increase in 2008.

This trend is reflected among all other groups of sample companies. With a slight decrease for both numbers and percentage of female directors, these sample companies show a slowly increasing trend during the ten years. Overall, all figures used have shown modest growth from 2001 to 2010 


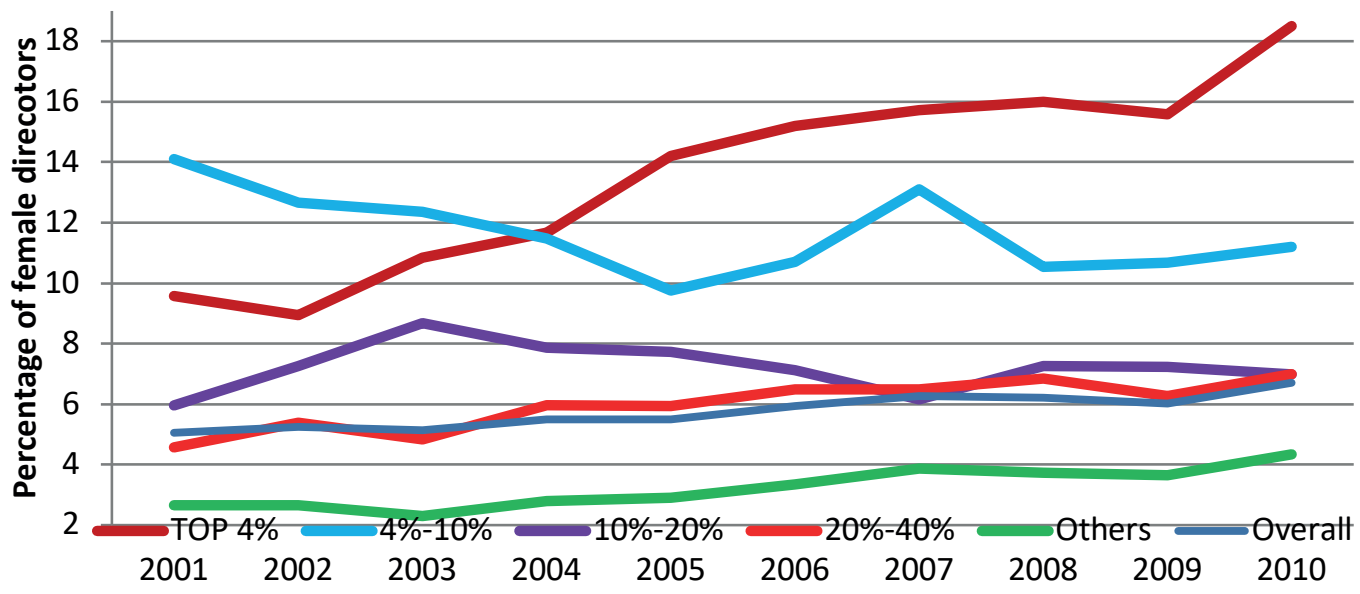

Figure 4 Percentage of female directors and company size (2001-2010).

Overall

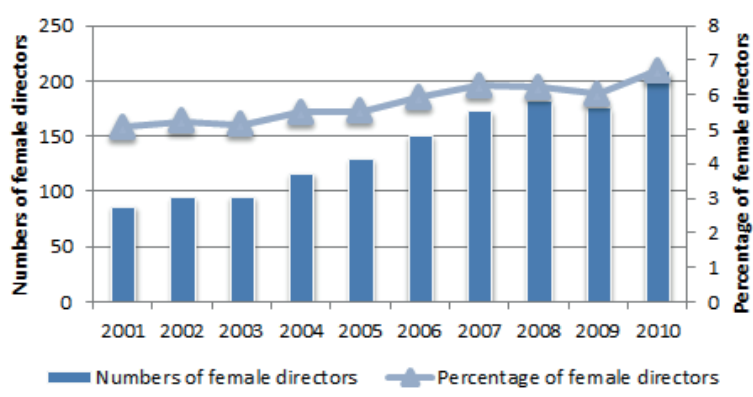

RANK 4\%-10\%

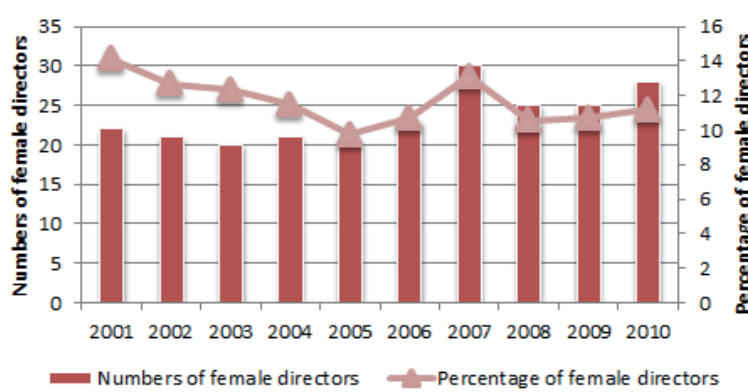

RANK $20 \%-40 \%$

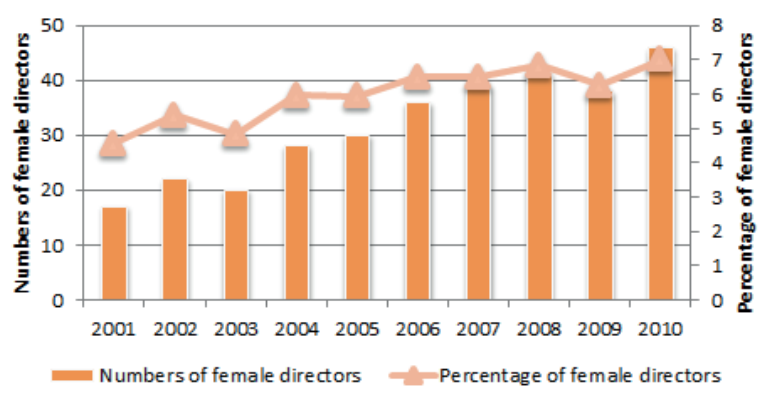

TOP $4 \%$

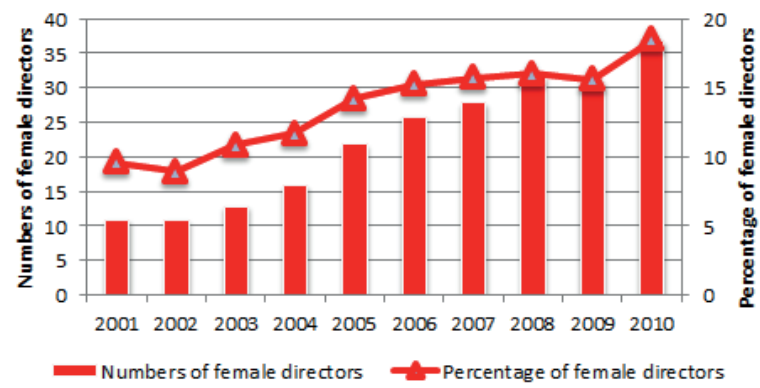

RANK $10 \%-20 \%$

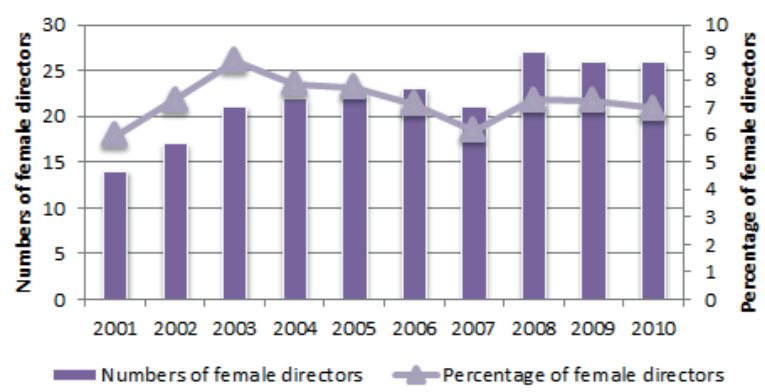

RANK Others

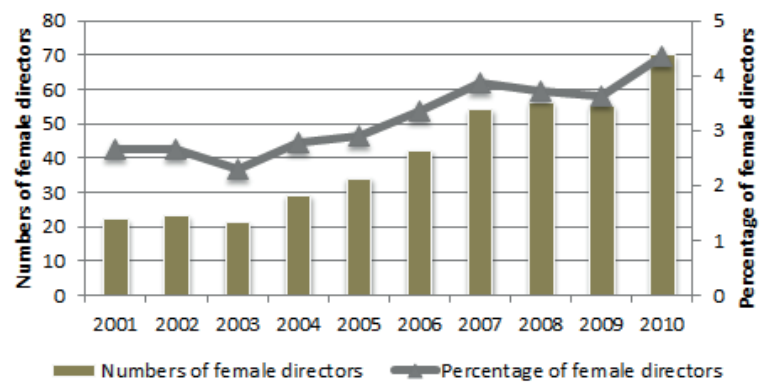

Figure 5 Number \& percentage of female directors and company size (2001-2010) 


\section{Industry representation of female directors}

Industry sectors show a significant divergence in female director representation across sample companies. In this study, the industries of each sample company are distinguished by their Global Industry Classification Standard (GICS) group code ${ }^{5}$. All the analysis in this thesis is at the GICS group level. The sample observations and the percentage of female directors in the sample companies in this study based on GICS are shown in Table 4.

5 GICS is a joint Standard and Poor's / Morgan Stanley Capital International product, which standardises industry definitions. GICS consists of 10 Sectors aggregated from 24 Industry Groups, 67 Industries, and 147 Sub-Industries. Resource from http://www.asx.com.au/products/gics htm 


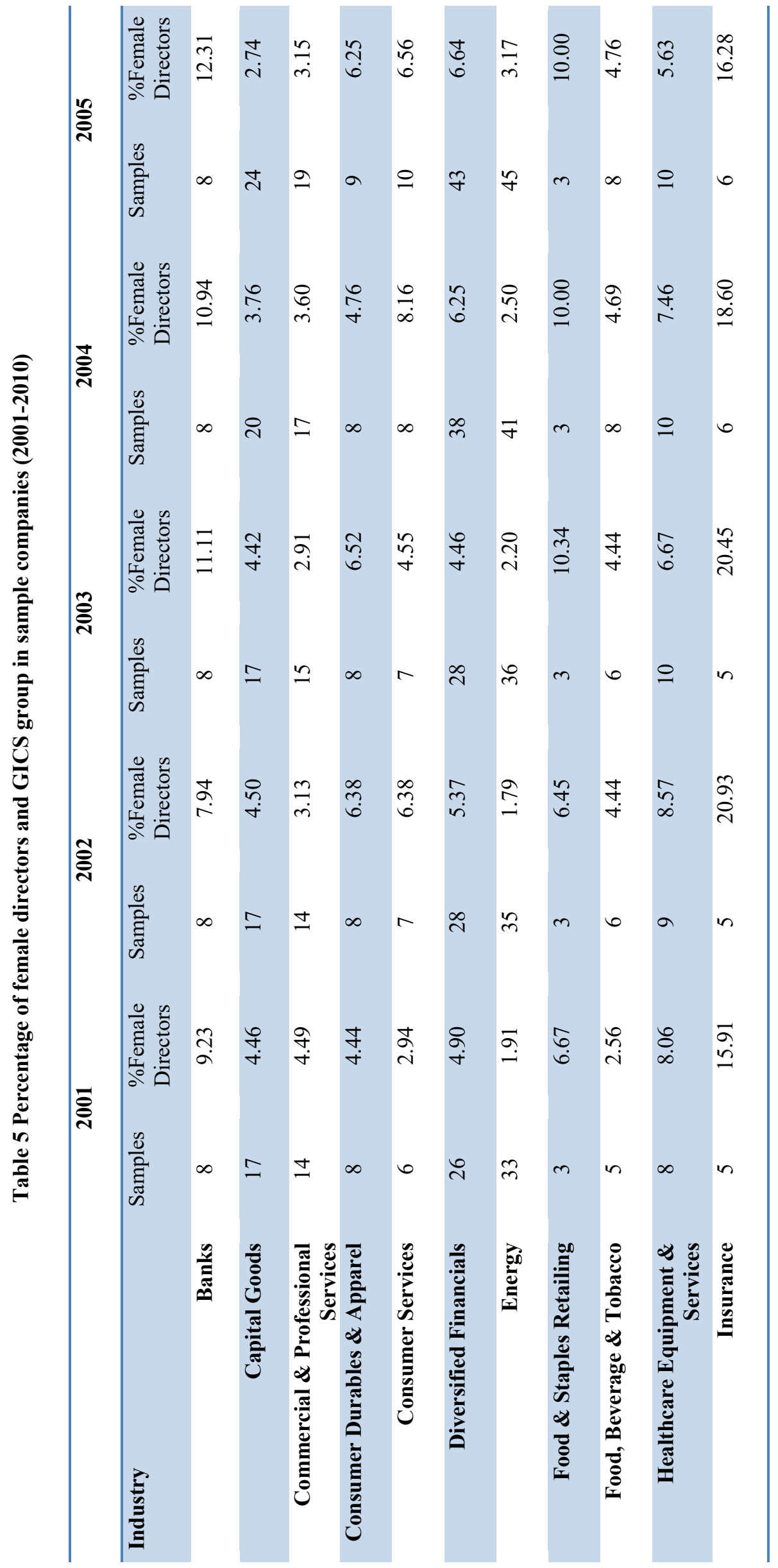




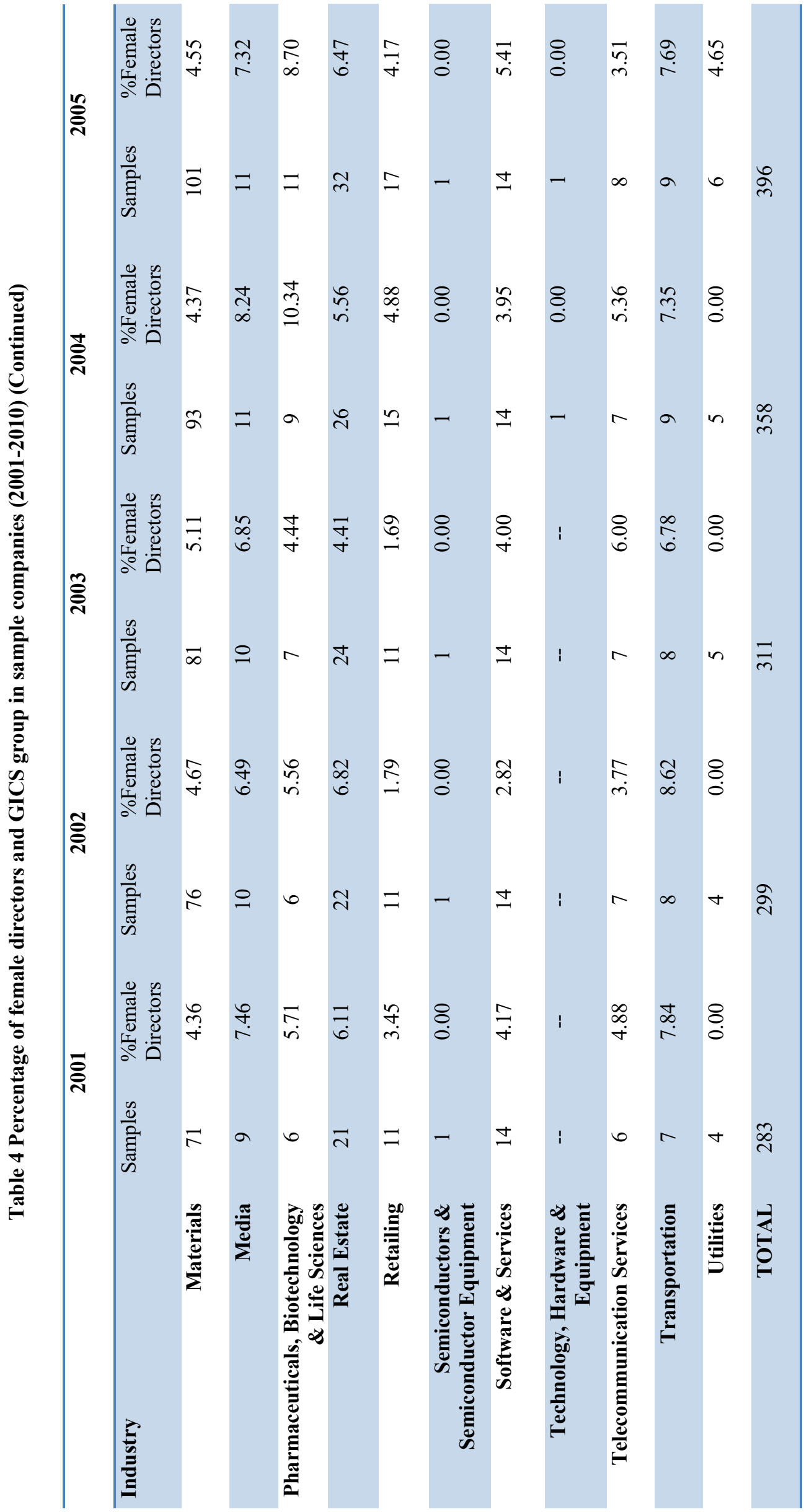




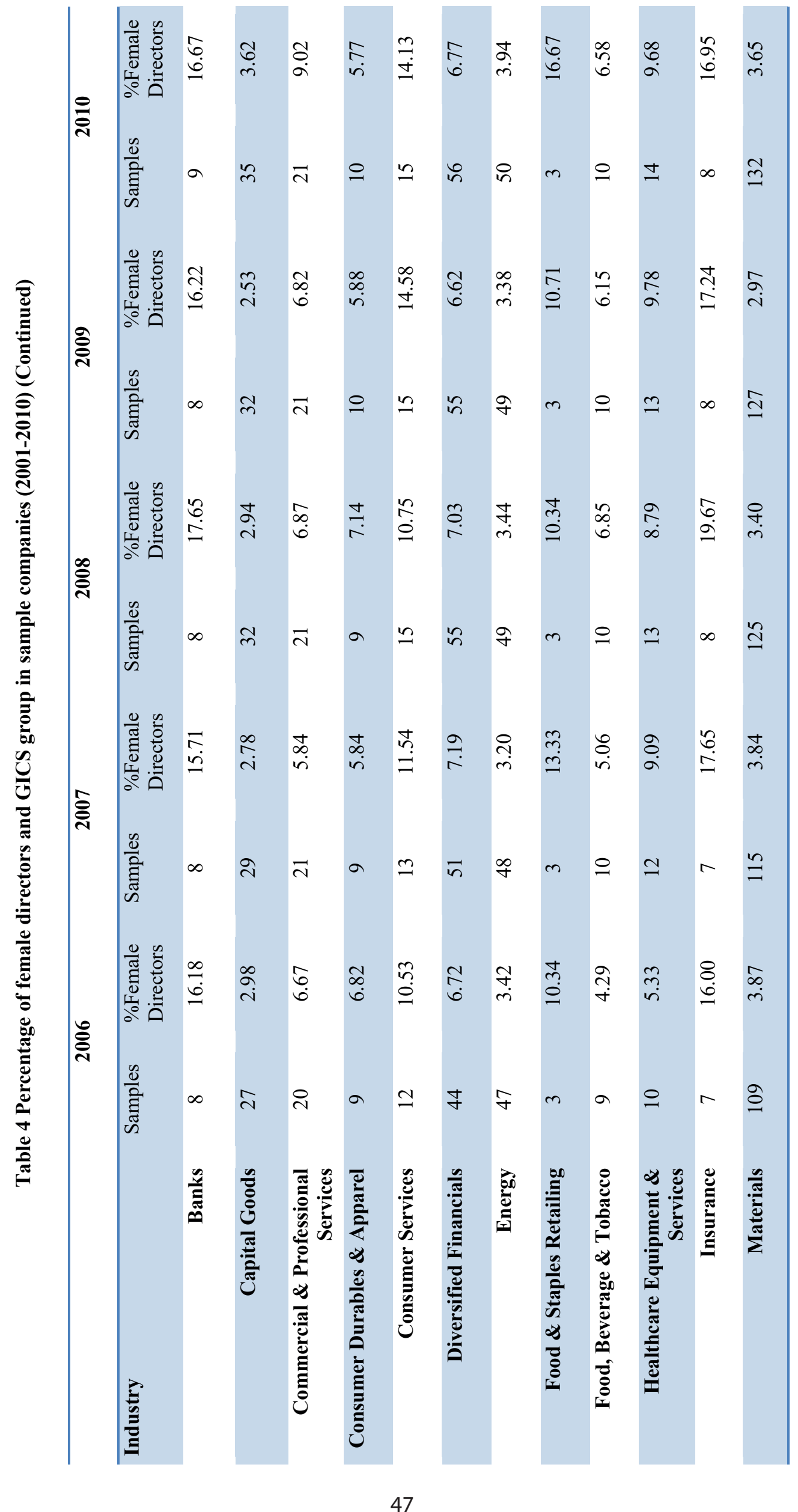




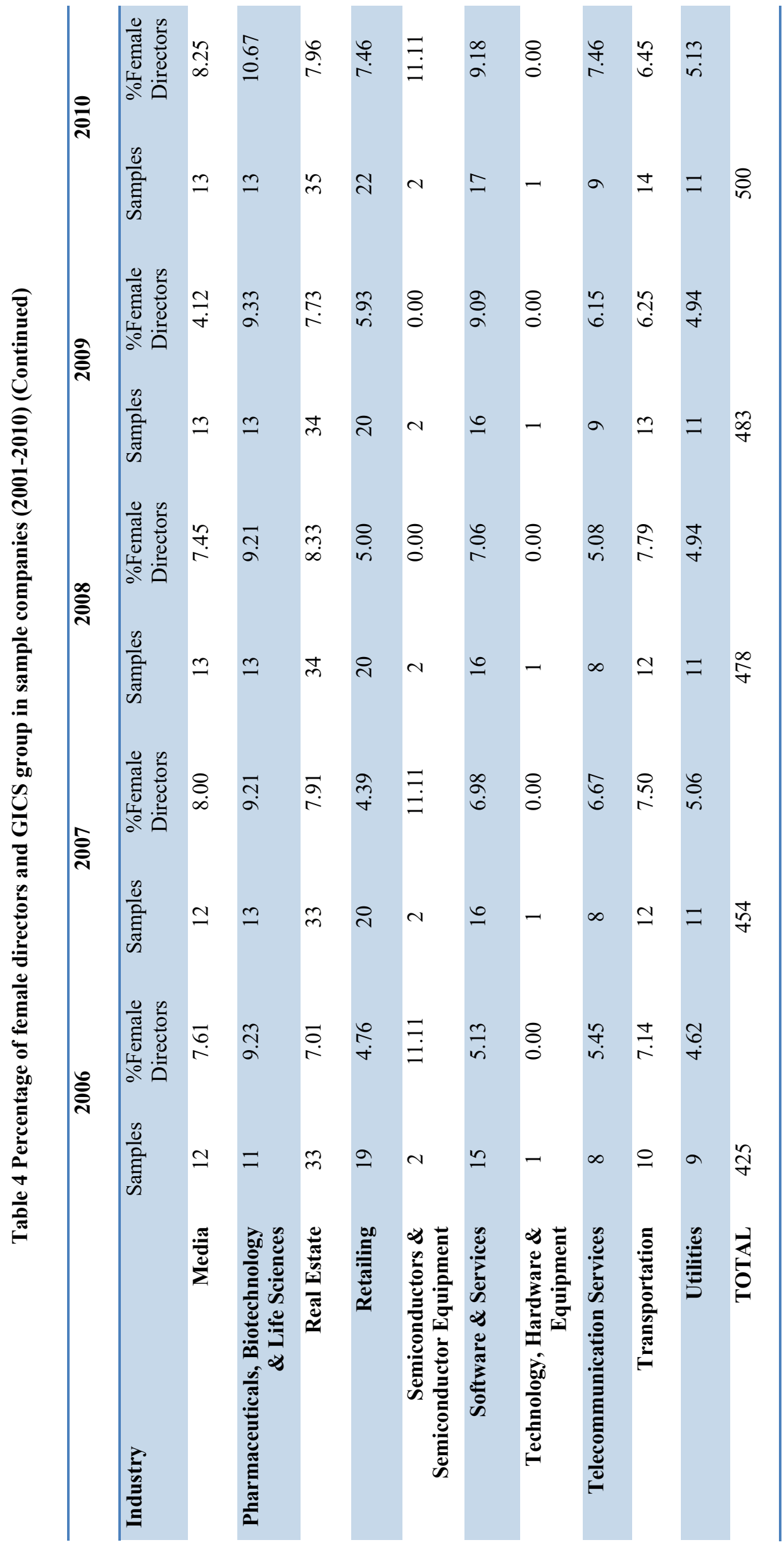


To compare female director representation in different industries more intuitively, the best and worst five companies in relation to their percentage of female directors are listed in Table 5.

Table 5 Best and worst performing industries of female director representation in sample companies (2001-2010)

\begin{tabular}{|c|c|c|}
\hline & Best Performing & Worst Performing \\
\hline \multirow{5}{*}{$\overline{\mathrm{d}}$} & Insurance & $\begin{array}{l}\text { Semiconductors \& Semiconductor } \\
\text { Equipment }\end{array}$ \\
\hline & Banks & Utilities \\
\hline & Healthcare Equipment \& Services & Energy \\
\hline & Transportation & Food, Beverage \& Tobacco \\
\hline & Media & Consumer Services \\
\hline \multirow{5}{*}{ ֶి } & Insurance & $\begin{array}{l}\text { Semiconductors \& Semiconductor } \\
\text { Equipment }\end{array}$ \\
\hline & Transportation & Utilities \\
\hline & Healthcare Equipment \& Services & Energy \\
\hline & Banks & Retailing \\
\hline & Real Estate & Software \& Services \\
\hline \multirow{5}{*}{$\hat{\delta}$} & Insurance & $\begin{array}{l}\text { Semiconductors \& Semiconductor } \\
\text { Equipment }\end{array}$ \\
\hline & Banks & Utilities \\
\hline & Food \& Staples Retailing & Retailing \\
\hline & Media & Energy \\
\hline & Transportation & Commercial \& Professional Services \\
\hline \multirow{5}{*}{ 官 } & Insurance & Technology, Hardware \& Equipment \\
\hline & Banks & $\begin{array}{l}\text { Semiconductors \& Semiconductor } \\
\text { Equipment }\end{array}$ \\
\hline & Pharmaceuticals, Biotechnology \& Life Sciences & Utilities \\
\hline & Food \& Staples Retailing & Energy \\
\hline & Media & Commercial \& Professional Services \\
\hline
\end{tabular}


Table 5 Best and worst performing industries of female director representation in sample companies (2001-2010) (Continued)

\begin{tabular}{|c|c|c|}
\hline & Best Performing & Worst Performing \\
\hline \multirow{5}{*}{$\stackrel{\overbrace{}}{\S}$} & Insurance & Technology, Hardware \& Equipment \\
\hline & Banks & $\begin{array}{l}\text { Semiconductors \& Semiconductor } \\
\text { Equipment }\end{array}$ \\
\hline & Food \& Staples Retailing & Capital Goods \\
\hline & $\begin{array}{l}\text { Pharmaceuticals, Biotechnology \& Life } \\
\text { Sciences }\end{array}$ & Commercial \& Professional Services \\
\hline & Transportation & Energy \\
\hline \multirow{5}{*}{ 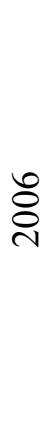 } & Banks & Technology, Hardware \& Equipment \\
\hline & Insurance & Capital Goods \\
\hline & Semiconductors \& Semiconductor Equipment & Energy \\
\hline & Consumer Services & Materials \\
\hline & Food \& Staples Retailing & Food, Beverage \& Tobacco \\
\hline \multirow{5}{*}{ ¿্ণ } & Insurance & Technology, Hardware \& Equipment \\
\hline & Banks & Capital Goods \\
\hline & Food \& Staples Retailing & Energy \\
\hline & Consumer Services & Materials \\
\hline & Semiconductors \& Semiconductor Equipment & Retailing \\
\hline \multirow{5}{*}{$\stackrel{\infty}{\stackrel{0}{\circ}}$} & Insurance & Technology, Hardware \& Equipment \\
\hline & Banks & $\begin{array}{l}\text { Semiconductors \& Semiconductor } \\
\text { Equipment }\end{array}$ \\
\hline & Consumer Services & Capital Goods \\
\hline & Food \& Staples Retailing & Materials \\
\hline & $\begin{array}{l}\text { Pharmaceuticals, Biotechnology \& Life } \\
\text { Sciences }\end{array}$ & Energy \\
\hline
\end{tabular}


Table 5 Best and worst performing industries of female director representation in sample companies (2001-2010) (Continued)

\begin{tabular}{|c|c|c|}
\hline & Best Performing & Worst Performing \\
\hline \multirow{5}{*}{ ஓे } & Insurance & Technology, Hardware \& Equipment \\
\hline & Banks & $\begin{array}{l}\text { Semiconductors \& Semiconductor } \\
\text { Equipment }\end{array}$ \\
\hline & Consumer Services & Capital Goods \\
\hline & Food \& Staples Retailing & Materials \\
\hline & Healthcare Equipment \& Services & Energy \\
\hline \multirow{5}{*}{$\stackrel{\circ}{\stackrel{2}{2}}$} & Insurance & Technology, Hardware \& Equipment \\
\hline & Banks & Capital Goods \\
\hline & Food \& Staples Retailing & Materials \\
\hline & Consumer Services & Energy \\
\hline & Semiconductors \& Semiconductor Equipment & Utilities \\
\hline
\end{tabular}

As shown in Table 5, the industries containing sample companies with the highest percentage of female directors have remained fairly consistent from 2001 to 2010, as have those with underrepresentation of female directors. The Insurance and Banking sectors in particular have consistently held the highest representation out of the sample companies over the decade. Food \& Staples, Retailing and Consumer Services have also been among the top five best industry sectors for female representation in most of the years from 2001 to 2010. Notably, there are only three sample companies included in the Food \& Staples Retailing sector and two in the Semiconductors \& Semiconductor Equipment sector. This suggests that the above result may not be entirely representative for the whole of these two industries. Generally speaking, companies in the Insurance and Banking sectors are most likely to have a gender-diverse board: an assessment supported by the census of EOWA (2010) and EOWA (2012). The difference of the representation of female directors on boards has already been emphasised by some empirical studies (Farrell \& Hersch, 2005; Harrigan, 1981; Hillman et al., 2007; Kang, Cheng, \& Gray, 2007). In addition, some researchers found that female directors are more likely to serve in service and financial companies (Harrigan, 1981; Hyland \& Marcellino, 2002). There are several reasons which may explain the differences of female director representation in different industries, one of which is the female employment rate (Hillman et al., 2007). Based on the data of the Australian Bureau of Statistics ${ }^{141}$, employment distribution of genders varies in industries (see Figure 6). In Figure 6, it is shown clearly that by the end of November 2010, the female employment rate is higher in the industries of Health Care and Social Assistance, Education and Training, Retail Trade, Accommodation and Food Services, Public Administration and Safety, Financial and Insurance Services, Administrate and Support Services. As the companies in these industries have a larger female employment base, it is expected that these companies may have more female directors (Hillman et al., 2007).

${ }^{141}$ Source from 4125.0 - Gender Indicators, Australia, Jan 2012. Australian Bureau of Statistics. http://www.abs.gov.au/ausstats/abs@nsf/Lookup/by+Subject/4125.0 Jan+2012 Main+Features $\sim$ Labour+force 1110 
EMPLOYMENT DISTRIBUTION BY INDUSTRY (a)(b), 2010-11 (c)

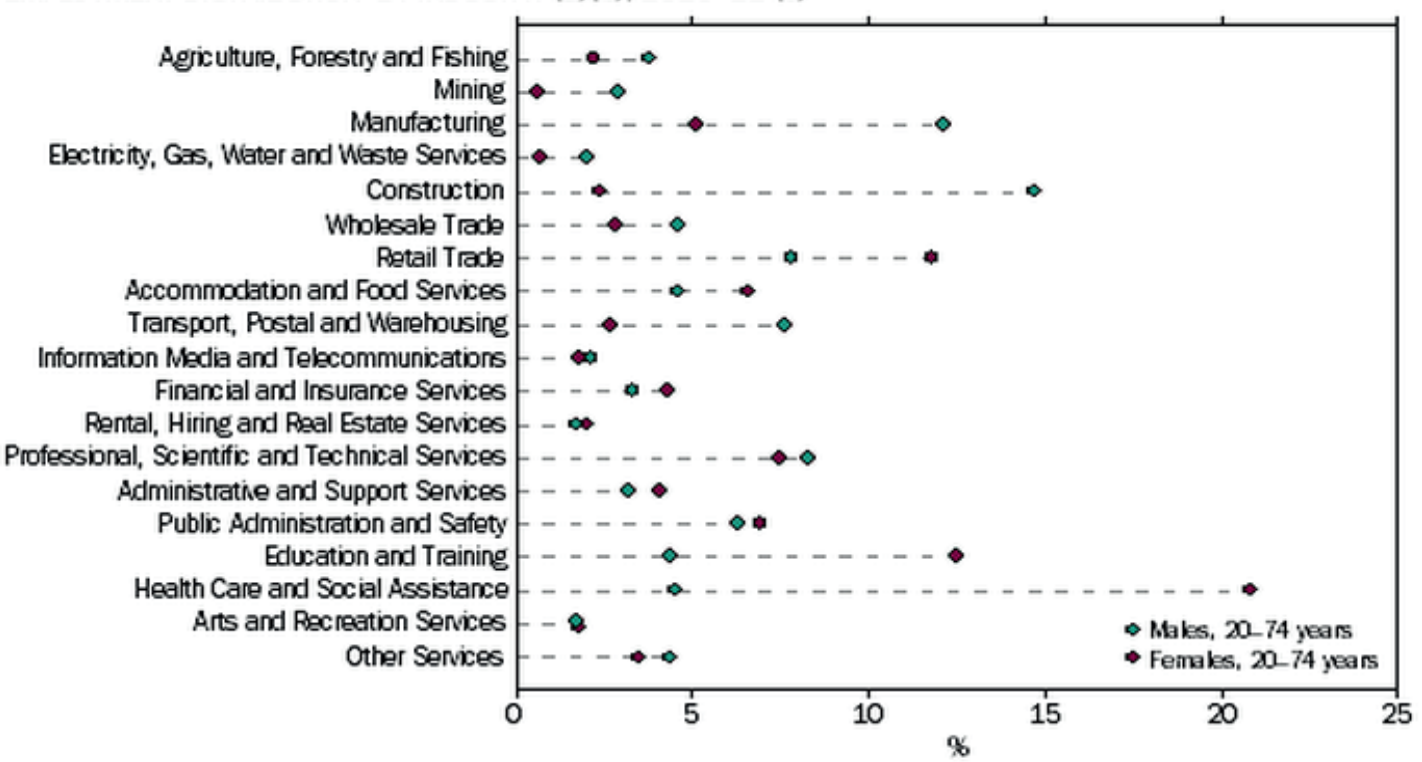

(a) Industry classified acoording to ABS Australian and New Zealand Standand Industrial Classification (ANZSC), 2006 (cat, mo, 1292.0), (b) As a proportion of total employed for males and fernales.

(c) Data were calculated as an average of 4 quarters (August, Nowember, February, May) in the firancial year.

Source: ABS dxa arailabie on reques, Labour Force Survey.

Figure 6 Female employments by industry (2010)

Source: Australian Bureau of Statistics (2012).

In addition, based on the occupational background of female directors in sample companies (details in the following section), it can be seen that a large number of female directors have a professional background, especially in accounting, finance and banking. It seems reasonable to assume that these female directors would use this skill set to contribute to corporate decision-making and operating processes, especially in financial sectors such as Insurance and Banking.

The worst performing industries have also remained constant from 2001 to 2010 among the sample companies, with the low performers being the Energy, Semiconductors \& Semiconductor Equipment, Technology, Hardware \& Equipment, Capital Goods, Materials and Utilities industry sectors. However, it should be noted that there is only one sample company included in the Technology, Hardware \& Equipment sector and two in the Semiconductors \& Semiconductor Equipment sector. Generally speaking, Energy and Materials, as well as Capital Goods and Utilities appear fairly consistently at the bottom rung of female director representation. These findings are consistent with the results of EOWA censuses (EOWA, 2000, 2010, 2012) and are not considered surprising due to the tendency of masculine-oriented industries such as Engineering, Building, Construction and Utilities to claim difficulties in finding female directors in practice (Harrigan, 1981; Sealy, Vinnicombe, \& Singh, 2008).

As distinct from these general trends of consistently high or low representation, the Semiconductors \& Semiconductor Equipment, and Consumer Services sectors have shown differing results over time. As mentioned above, only two sample companies were classified as Semiconductors \& Semiconductor Equipment companies. Therefore, the results of this industry are significantly influenced by the performance of Dyesol Limited; one of the two companies from this industry. In contrast, the Consumer Services sector followed a different trend. Although female director representation was relatively low in 2001, this industry has shown a significant increase since 2003 resulting in it being one of the five highest industries for female director representation over five years. 


\section{Female directors and their formal role in companies}

This section describes female director representation and their role within corporations.

\section{Female director representation and leadership}

Female representation in leadership positions in corporations has undergone a similar trend as that outlined previously in regards to industries. As Figure 7 shows, both the percentage of female chairpersons and female Chief Executive Officers (CEOs) showed an upward trend at the end of 2010. Of the sample companies there has been an irregular but increasing pattern of representation of women in these positions; with performance in this area decreasing slightly between 2001 and 2003 (by 1.06 percent), with the exception of the years 2006 to 2008 , which despite a temporary drop in representation still saw five female chairpersons. This somewhat erratically upward trend is echoed in female CEO representation in the sample companies, which increased to 1.67 percent in 2002, dropped to 1.29 percent in 2003, and has been steadily increasing since 2006, as reflected in the findings of EOWA (2012). In summary, the percentage of female CEOs is dramatically less than male CEOs although it has increased from 0.71 percent in 2001 to 3.20 percent in 2010.

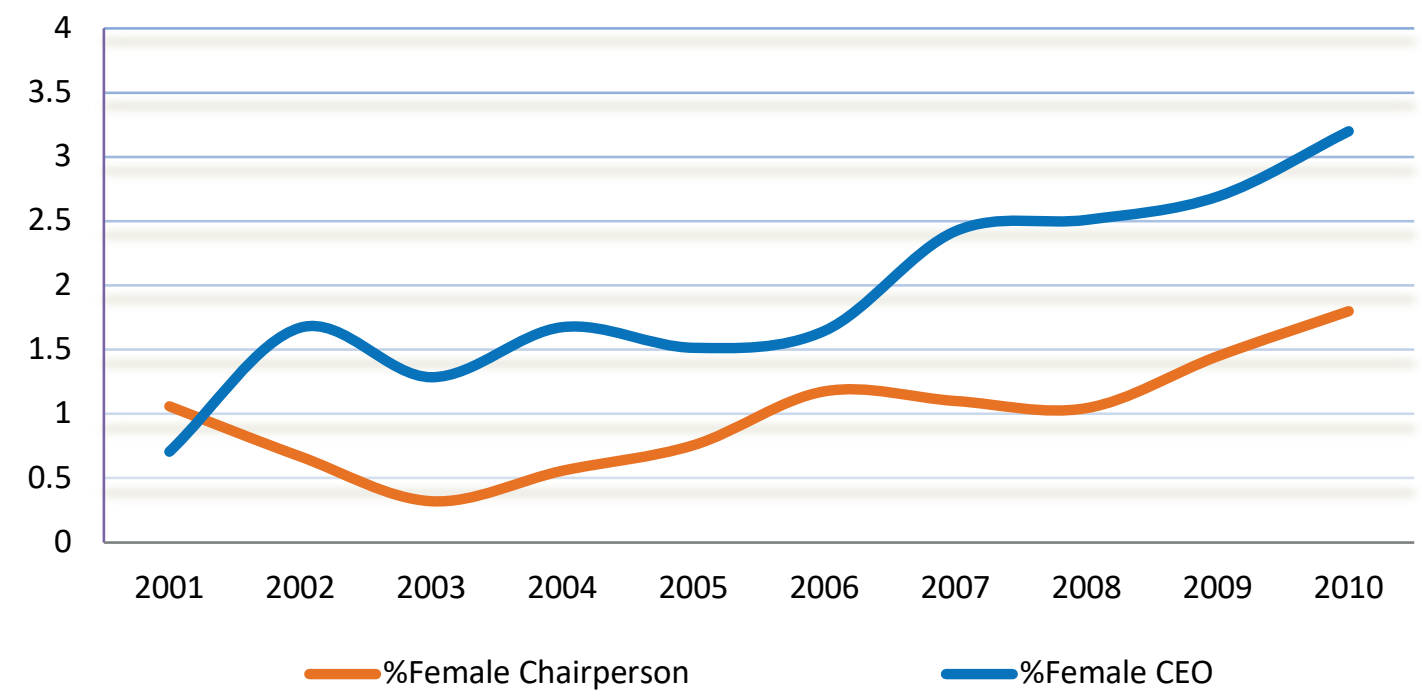

Figure 7 Female representation in leadership positions (2001-2010)

\section{Female director representation and board size}

Some researchers (Campbell \& Minguez-Vera, 2008; Carter et al., 2003) find that in larger boards there is a greater probability of female directors being selected. Figure 8 indicates the distribution of board size for the sample companies. 


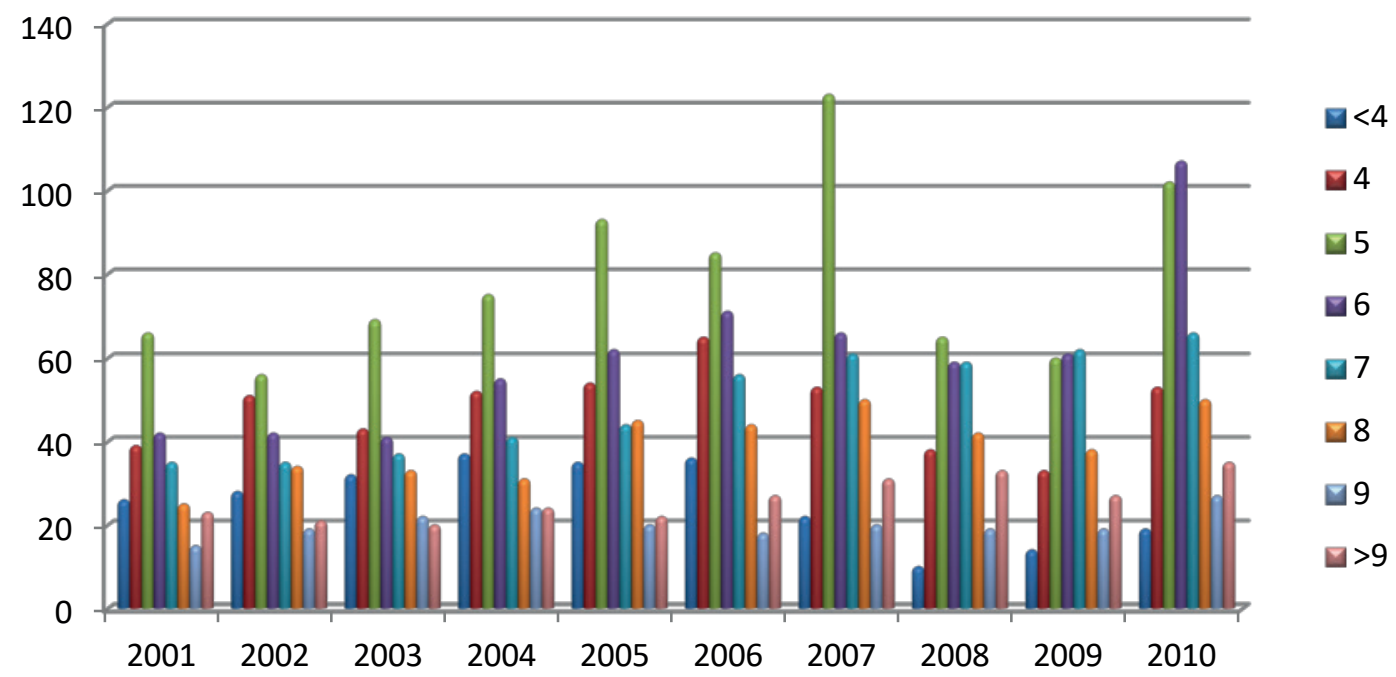

Figure 8 Distribution of board size in sample companies (2001-2010)

From Figure 8, most sample companies have five to six directors on their boards, with board sizes marginally increasing since 2007.

Figure 9 and Figure 10 show the average board size and the total number of female directors and average board size and percentage of female directors in the sample companies from 2001 to 2010 respectively.

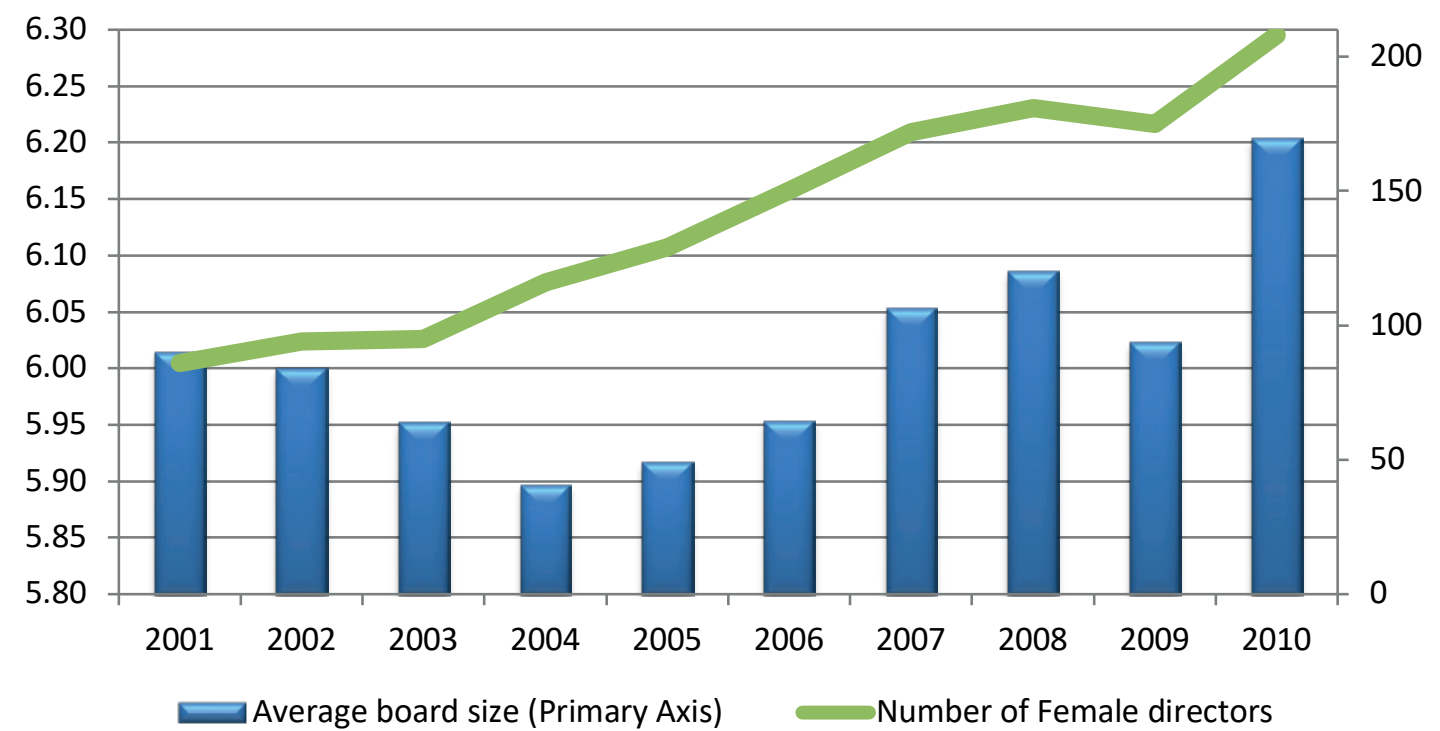

Figure 9 Number of female directors and board size (2001-2010) 


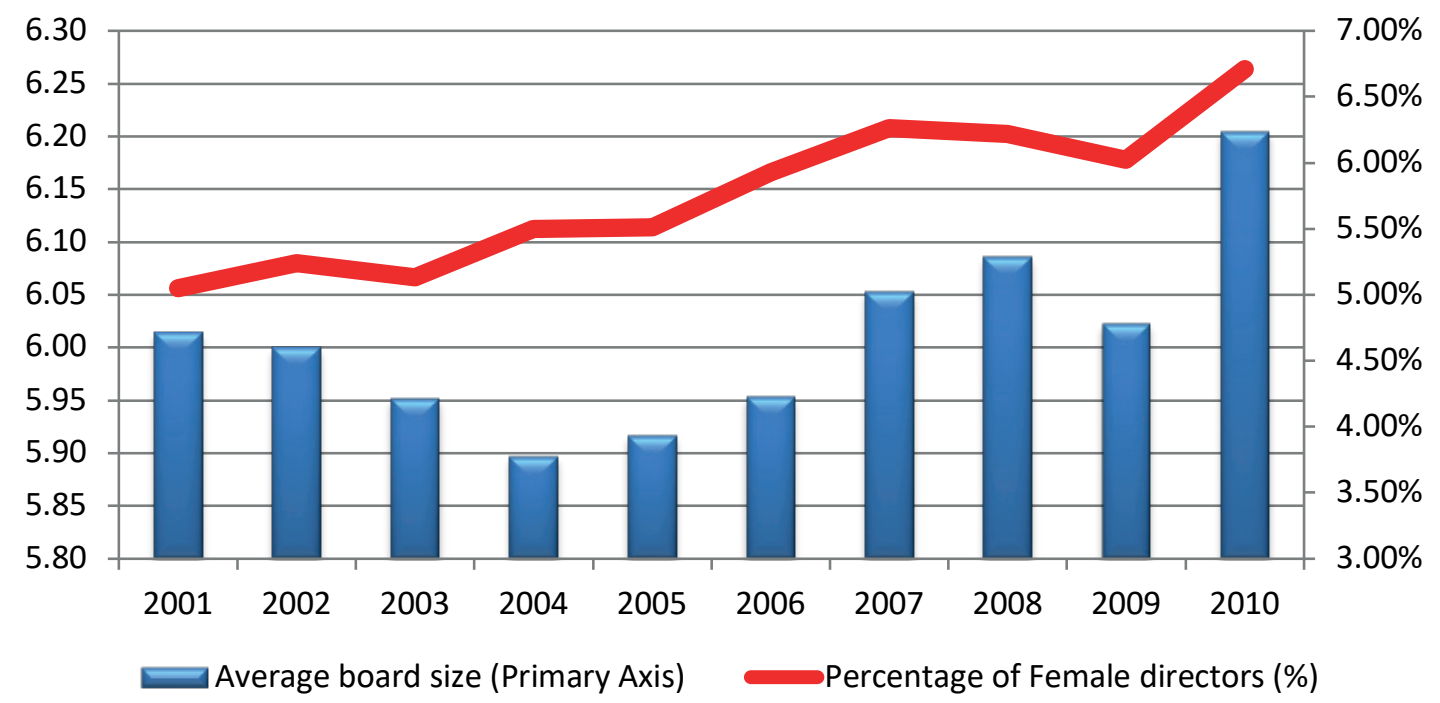

Figure 10 Percentage of female directors and board size (2001-2010)

As seen in the above figures, both the total number and percentage of female directors have grown alongside the average board size of the sample companies from 2004 to 2010. The average board size in the sample companies is 5-6 persons with a percentage of female directors at 6-7 percent. This percentage involves an increasing number of female directors from 86 in 2001 to 208 in 2010. As the figures do not show a visually significant relationship between female director representation and board size for all ten years, especially from the year 2001 to 2003, a Spearman's rank correlation coefficient is employed.

The Pearson correlation coefficient is the most widely used method to identify correlations between the variables. However, it is only applied to measure the strength of the linear relationship between normally distributed variables. As the data here is not normally distributed based on the normality test, a Spearman rank-order correlation coefficient is employed. Spearman's rank correlation is a nonparametric test and thus has no assumptions of normal distribution and sample size (Spearman, 1904).

Table 6 Spearman's correlation on female director representation and board size

\begin{tabular}{|l|l|l|l|}
\hline \multirow{2}{*}{ Number of female directors } & \multicolumn{2}{|l|}{ Board Size } & \multicolumn{2}{|l|}{-value } \\
\cline { 2 - 4 } & Observations & Spearman's rho & 0.0000 \\
\hline Percentage of female directors & 3,987 & 0.4243 & 0.0000 \\
\hline
\end{tabular}

The null hypothesis of the Spearman's correlation test is that the two variables are independent. As the results show, $p$-values of both number and percentage of female directors are 0.0000 , which indicates that the null hypotheses are both rejected. In general, there are monotonic relationships between number of female directors and board size, and between the percentage of female directors and board size. The positive Spearman's rho (coefficient) reveals that a larger board is associated with a greater number and a higher percentage of female directors. Notably, the association between number of female directors and board size is even stronger than between the percentage of female directors and board size. 


\section{Female director representation and board committees}

The Australian Institute of Company Directors emphasises the importance of establishing committees of directors for companies, especially for large organisations, to deal with complex and specialised issues. These initiatives are also required by the law and regulators such as the Corporations Act 2001, ASX Corporate Governance Council's Corporate Governance Principles and Recommendations and the Australian Prudential and Regulation Authority (APRA) ${ }^{142}$.

All companies listed on the ASX are recommended (ASX Revised Corporate Governance Principles and Recommendations, 2007; Corporate Governance Principles and Recommendations with 2010 Amendments, 2010; Corporate Governance Principles and Recommendations third edition, 2014) to establish at least three board committees: an Audit Committee, Nomination Committee and Remuneration Committee (Kesner, 1988). These three committees focus on important board responsibilities and are thus seen as important formal committees of review. The Audit Committee is charged with "overseeing companies' financial reporting and disclosure", the Nomination Committee is responsible for "evaluating the board of directors and examining the skills and characteristics of nominees" and the Remuneration Committee focuses on "deciding on the pay and incentive schemes for executive directors" (EOWA, 2012). Figure 11 and Figure 12 show the numbers of female directors serving on these committees and the number of female directors holding committee chairs on these committees.

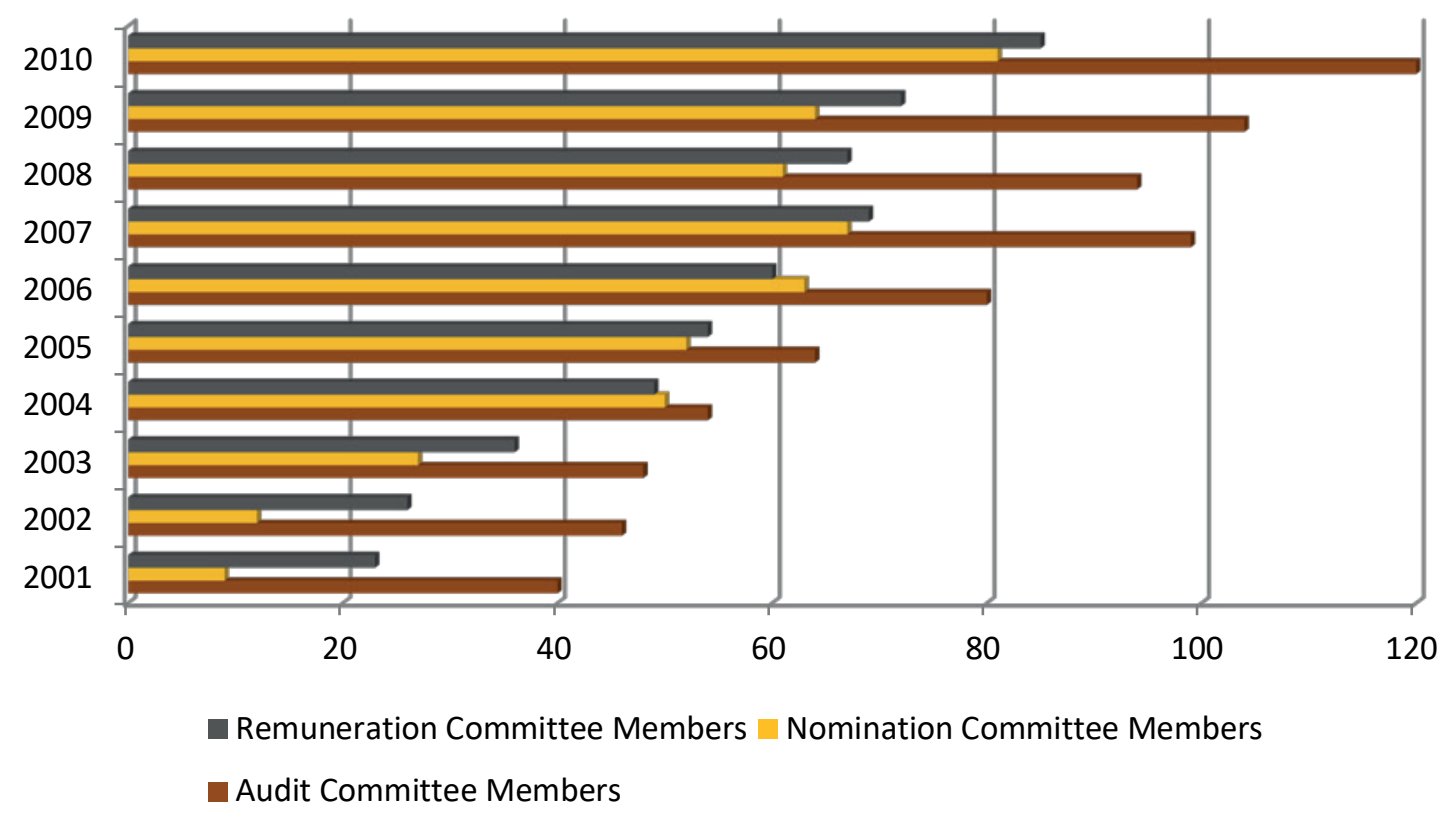

Figure 11 Female director representation on board committees (2001-2010)

\footnotetext{
${ }^{142}$ Source from the Australian Institute of Company Directors, http://www.companydirectors.com.au/Director-ResourceCentre/Director-QA/Roles-Duties-and-Responsibilities/Board-Committees.
} 


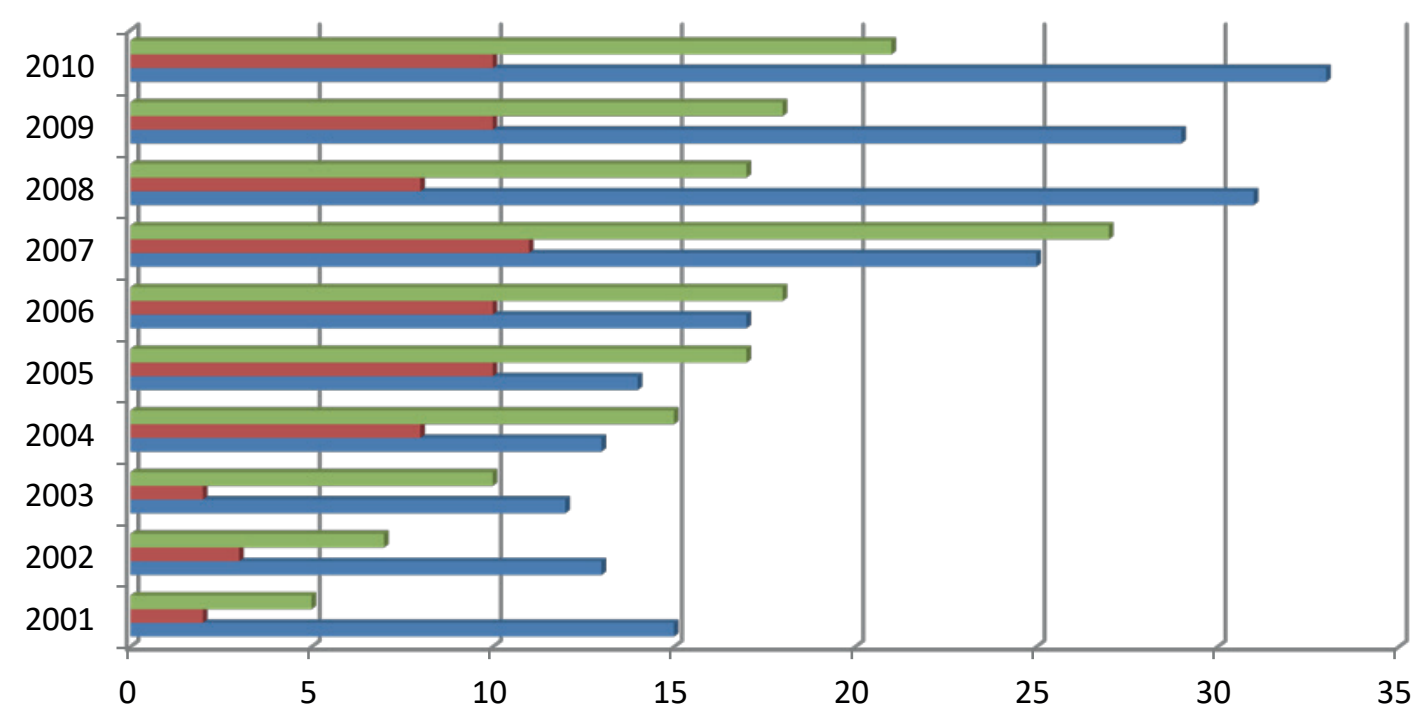

Remuneration Committee Chairs $\square$ Nomination Committee Chairs $\square$ Audit Committee Chairs

Figure 12 Female directors holding committee chairs (2001-2010)

As shown in the above figures, female directors are more likely to serve on the Audit Committee than on any other committee, though it might be noted that there has been a significant increase of the number of female directors on the Nomination Committee from 2001 to 2010. Despite this increase however, the Nomination committee has remained dominated by male committee chairpersons since 2001. In addition, female directors are more likely to chair Audit Committee and Remuneration Committee. These findings are supported by the census of EOWA (2012).

\section{Individual descriptions of female directors}

This section describes female director representation based on the individual characteristics.

\section{Female directorships}

In the sample companies, some female directors held directorships in more than one company. Figure 13 reveals the number of female directors holding multiple directorships in the sample companies.

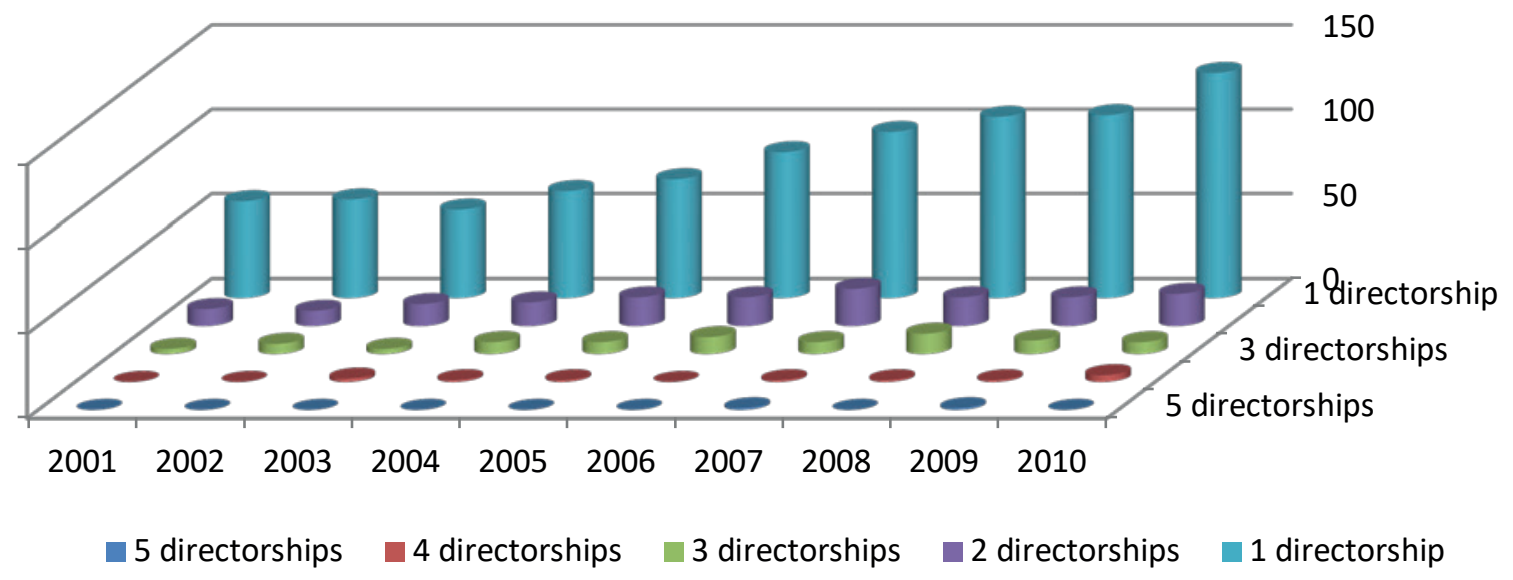

Figure 13 Directorships of female directors in sample companies (2001-2010) 
As seen in Figure 13, most female directors held only one directorship. However between 13 (in 2001) to 30 (in 2010) female directors held multiple directorships and served on at least two sample company boards in the same year, and nearly all of them served on the largest 200 sample companies based on their market capitalisation or their total assets. This result may be considered unsurprising on account of the high standards female directors in these companies generally hold in terms of qualification and reputation. As expressed by one female ASX 200 director, "I think because I am on a few boards - there are lots of invitations to join boards - really it is no reflection on me other than the fact that I've been tested and I'm female" (EOWA, 2012).

\section{Occupational background}

As performed in previous censuses by EOWA, the occupational backgrounds of female directors are categorised in this study in one of four different groups: executive (senior executive experience), professional (legal, accounting and finance experience), support (human resource, consulting experience and specific experience in a certain industry), and public (public service experience such as regulator and academic).

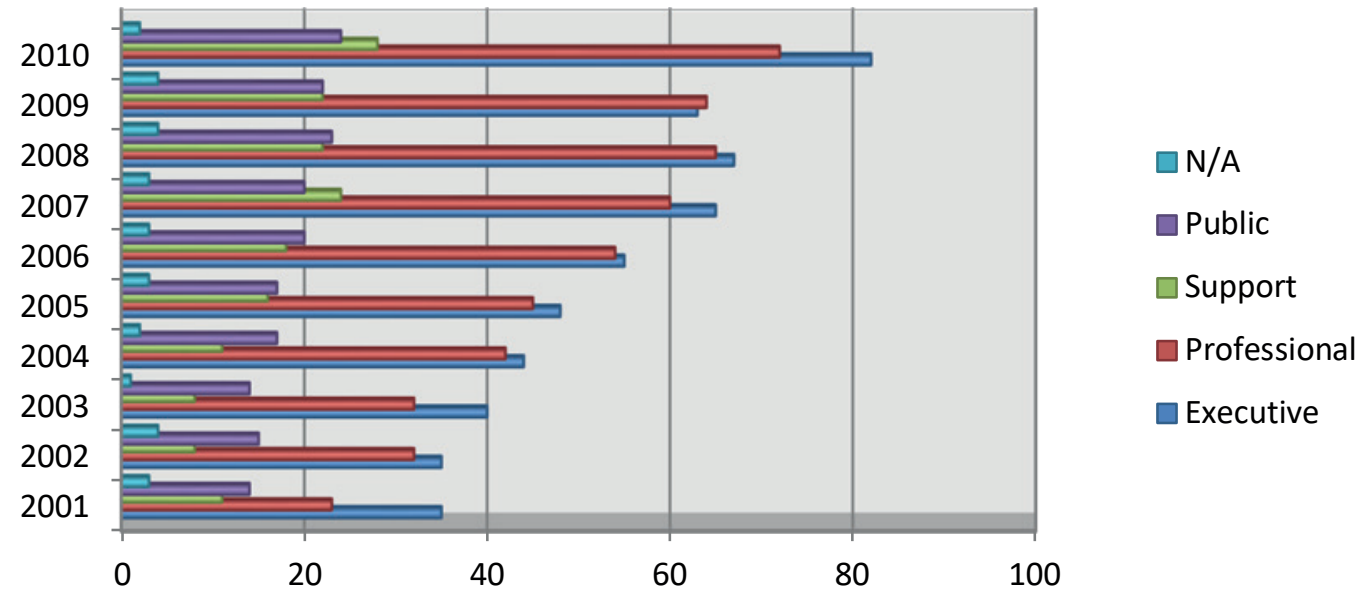

Figure 14 Occupational backgrounds of female directors in sample companies (2001-2010)

Figure 14 demonstrates the distribution of female directors' occupational backgrounds in the sample companies. As seen in this figure, female directors with senior executive experience and professional backgrounds are strongly representative of the whole group. It would also appear that female directors with professional backgrounds as well as those with senior executive experience are most likely to be on company boards during the years from 2001 to 2010 . 


\section{Entire Observations}

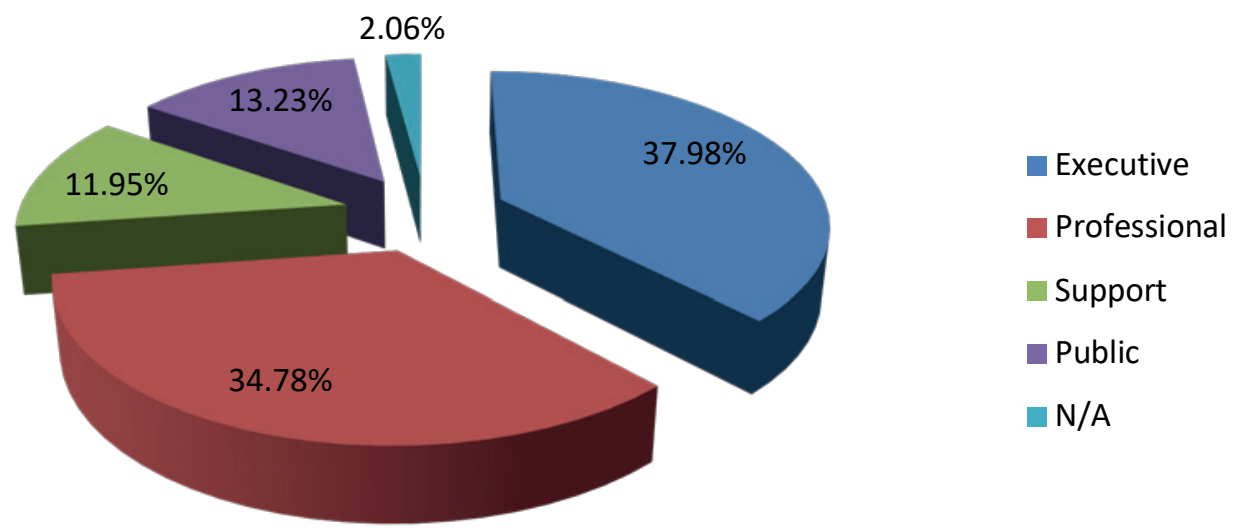

Figure 15 Occupational backgrounds of female directors (Entire Observations)

Figure 15 reveals the distribution of female directors' occupational backgrounds in this study's entire observations over the decade from 2001 to 2010. In general, female directors with executive backgrounds appear to be the most common group in the sample companies. Companies also seem willing to include on their boards female directors with experience and a background in law, accounting and finance. In addition, within the sample companies there are more female directors with public service experience as regulators, politicians or academics than those with corporate or specific industry experience.

\section{Study Results}

This article so far has provided snapshots of female director representation from a general, industry, corporate and individual level. A clear picture can thus be drawn of female director representation and how it has changed from 2001 to 2010 in the largest 500 companies in Australia.

From 2001 to 2010, female director representation (including the number and percentage of female directors, the number and percentage of female chairpersons and female CEOs) and companies with at least one female director have all increased. Based on the figures indicating a relationship between female directors and company size, larger companies have a higher percentage of female directors than smaller companies, with female director representation in the largest $20 \%$ of companies being significantly higher than the overall level of sample companies.

In terms of different industry sectors, female director representation has shown a significant divergence. However, the sectors with the highest and lowest percentage of female directors have all remained consistent from 2001 to 2010. Female directors consistently have more seats in the boardrooms of Insurance and Banking companies; while in some traditionally masculine-led industries, such as Energy, Materials and Utilities, female directors have been under-represented.

Notably the study finds not only that larger boards have greater numbers of female directors, (a point which has been argued and shown by many other researchers), but also that larger boards have a greater percentage of female directors. In the sample companies, those with more directors are more likely to embrace a diverse board with greater female director representation.

With respect to committee representation, female directors are most likely to serve on Audit Committee and are more likely to chair Audit Committee and Remuneration Committee. These results are not surprising as more than one third of female directors have executive and professional (legal, accounting and finance) backgrounds, which are relevant to these responsibilities. 
Although most of the female directors of the sample companies have only one directorship, there are nearly 30 female directors in 2010 who held at least two company directorships in the sample companies. Almost all of these women serve on the largest 200 companies.

The findings of this article provides a useful introduction into the board question of what impact female directors had on company activities and performance during this time, which may be supportive of direction of future study focusing on the association between female director characteristics and corporate performance. In addition, the results also examine the effectiveness of existing gender diversity initiatives and shed a light on future corporate governance proposals advocating greater gender diversity on company boards.

\section{References}

Adjaoud, F., \& Ben-Amar, W. (2010). Corporate governance and dividend policy: Shareholders' protection or expropriation? Journal of Business Finance \& Accounting, 37(5/6), 648-667. doi: $10.1111 /$ j. $1468-5957.2010 .02192 . x$

Campbell, K., \& Minguez-Vera, A. (2008). Gender diversity in the boardroom and firm financial performance. Journal of Business Ethics, 83(3), 435-451. doi: 10.1007/s10551-007-9630-y

Carter, D. A., Simkins, B. J., \& Simpson, W. G. (2003). Corporate governance, board diversity, and firm value. Financial Review, 38(1). doi: 10.1111/1540-6288.00034

Catalyst. (2014). Quick Take: Women on Boards. New York: Catalyst.

CWDI. (2012). Comparative Percentages of Women Directors. from http://www.globewomen.org/CWDI/CWDI-PERCENTAGES.htm

EOWA. (2000). EOWA Australian Census of Women in Leadership: Equal Opportunity for Women in the Workplace Agency.

EOWA. (2010). Australian Census of Women in Leadership: Equal Opportunity for Women in the Workplace Agency.

EOWA. (2012). Australian Census of Women in Leadership: Equal Opportunity for Women in the Workplace Agency.

Farrell, K. A., \& Hersch, P. L. (2005). Additions to corporate boards: The effect of gender. Journal of Corporate Finance, 11(1-2), 85-106. doi: 10.1016/j.jcorpfin.2003.12.001

Harrigan, K. R. (1981). Numbers and positions of women elected to corporate boards. Academy of Management Journal, 24(3), 619-625. doi: 10.2307/255580

Hillman, A. J., Shropshire, C., \& Cannella, A. A. (2007). Organizational predictors of women on corporate boards. Academy of Management Journal, 50(4), 941-952. doi: 10.5465/AMJ.2007.26279222

Hyland, M. M., \& Marcellino, P. A. (2002). Examining gender on corporate boards: A regional study. Corporate Governance: The international journal of business in society, 2(4), 24-31. doi: $10.1108 / 14720700210447669$

Jurkus, A. F., Park, J. C., \& Woodard, L. S. (2008). Women in top management and agency costs. Working Papers Series. Retrieved from http://ssrn.com/abstract $=1085109$

Kang, H., Cheng, M., \& Gray, S. J. (2007). Corporate governance and board composition: Diversity and independence of Australian boards. Corporate Governance: An International Review, 15(2), 194-207. doi: 10.1111/j.1467-8683.2007.00554.x

Kesner, I. F. (1988). Directors' characteristics and committee membership: An investigation of type, occupation, tenure, and gender. Academy of Management Journal, 31(1), 66-84. doi: $10.2307 / 256498$

Nielsen, S., \& Huse, M. (2010). The contribution of women on boards of directors: Going beyond the surface. Corporate Governance: An International Review, 18(2), 136-148. doi: $10.1111 / \mathrm{j} .1467-8683.2010 .00784 . \mathrm{x}$

Nielsen, S., \& Morten, H. (2010). Women directors' contribution to board decision-making and strategic involvement: The role of equality perception. European Management Review(7), 1629. 
O'Reilly III, C. A., \& Main, B. G. M. (2012). Women in the boardroom: Symbols or substance? Research Paper Series No.2098. Graduate School of Business, Stanford University.

Sealy, R., Vinnicombe, S., \& Singh, V. (2008). The pipeline to the board finally opens: Women's progress on FTSE 100 boards in the UK. In S. Vinnicombe, V. Singh, R. J. Burke, D. Bilimoria \& M. Huse (Eds.), Women on corporate boards of directors: International research and practice (pp. 37-46). Cheltenham: Edward Elgar Publishing Limited.

Spearman, C. (1904). The proof and measurement of association between two things. American Journal of Psychology, 15(1), 72-101. doi: 10.2307/1412159

Wellalage, N. H. (2011). Women on board, firm financial performance and agency costs. Working Papers Series. The University of Waikato. Retrieved from http://ssrn.com/abstract=1904072 
